\title{
THE CURRENT IMPLEMENTATION OF AN EVIDENCE-BASED HAMSTRING INJURY PREVENTION EXERCISE (NORDIC HAMSTRING EXERCISE) AMONG ATHLETES GLOBALLY
}

\author{
Wesam Saleh A. Al Attar $1,2,3 \mathrm{ABCDE}$ \\ ${ }^{1}$ Umm Al Qura University \\ ${ }^{2}$ The University of Sydney \\ ${ }^{3}$ University of Basel \\ Authors' Contribution: A - Study design; B - Data collection; C - Statistical analysis; D - Manuscript Preparation; E - Funds Collection
}

Corresponding Author: Wesam Saleh A., Al Attar, E-mail: wsattar@uqu.edu.sa

Accepted for Publication: September 17, 2021

Published: September 25, 2021

DOI: 10.17309/tmfv.2021.3.11

\begin{abstract}
Purpose. The Nordic hamstring exercise (NHE) has been shown to be successful in reducing hamstring muscle injury (HMI), which is one of the most common non-contact injuries of the lower limbs. This is especially pertinent in sports that require acceleration, maximal sprints, and sudden changes in the direction of running and sprinting, such as soccer and rugby. This study aimed to evaluate the awareness, implementation, and opinions of athletes worldwide regarding the effectiveness of NHE in preventing hamstring injury.

Materials and methods. A self-administered questionnaire was distributed to 1500 athletes from different sports. The survey consisted of six questions covering country, gender, type of sport, awareness, implementation, and opinions of athletes worldwide regarding the effectiveness of NHE in preventing hamstring injury. The survey was available in ten different languages.

Results. A total of 1142 male and female athletes from different sports participated in the survey. More than half of the athletes 641 (56\%) were aware of NHE, and only 519 (45.4\%) were implementing NHE in their current training routines. Athletes who implemented NHE reported a positive opinion regarding the program's effectiveness with a score of $8.4 \pm 1$ out of 10 .

Conclusions. Many athletes were aware of NHE and implemented it in their training routine since they found it to be effective in decreasing hamstring injury rates. However, additional work must be done to educate athletes about the importance of implementing this exercise and its effectiveness in preventing hamstring injury.

Keywords: hamstring muscles, muscle injury, athletes, surveys, questionnaires.
\end{abstract}

\section{Introduction}

The most common lower limb injuries in sports are hamstring muscle injuries (HMIs), which occur in sports involving high-speed running, such as rugby, baseball, basketball, soccer, and American football. HMIs are considered the most common noncontact injuries in these sports. However, they can also occur due to direct trauma to the muscle fibers (Reurink et al., 2014). Ueblacker et al. (2015) investigated the incidence of direct and indirect HMIs in 1981 players who were followed prospectively from 2001 to 2013; they scored 2287 HMIs and found that $88 \%$ of the injuries were indirect and $12 \%$ were direct.

(c) Wesam Saleh A. Al Attar, 2021.
There are two types of HMIs: stretch-type and sprinttype HMIs (Ekstrand et al., 2012). Stretch-type injuries are caused by a slow or sudden uncontrolled stretch that can occur in sports, such as dancing, gymnastics, and water skiing (Ekstrand et al., 2012). These injuries occur in the proximal free tendon of the semimembranosus muscle. In contrast, sprint-type injuries often occur in sports that involve running and cutting, such as Australian football, American football, soccer, and rugby (De Vos et al., 2014). Sprint-type HMIs usually occur in the late swing phase during sprinting when the hamstring submaximally stretches over the knee joint before the foot hits the ground (Chumanov et al., 2011).

Hamstring muscle injuries typically occur along the proximal musculotendinous junction but may also occur anywhere in the muscle belly between the origin and insertion 
(Ropiak et al., 2012). The severity of the injury can be estimated according to the number of days the athlete remains absent from training sessions or matches and is classified into four levels: minimal, 0-3 days; mild, 4-7 days; moderate, 8-28 days; and severe, $>28$ days (Hägglund et al., 2018).

HMIs represent one-third of all muscle strains and $11 \%$ of all injuries. Approximately 14\% of these HMIs can result in re-injury (Dadebo et al., 2004). In a prospective cohort study, Yeung et al. (2009) investigated the incidence of HMIs in competitive sprinters, and they found that eight of 44 sprinters had sustained hamstring injury over the season at a rate of 0.9 per $1000 \mathrm{~h}$ of exposure. An analysis of 23 European professional soccer teams from 2007 to 2011 revealed 516 HMIs, representing $11 \%$ of all injuries and onethird of all muscle strains (Ekstrand et al., 2012; Dadebo et al., 2004; Ekstrand et al., 2016).

In a longitudinal analysis of 36 clubs in 12 European countries, 1614 HMIs were recorded from 2001 to 2014, and while the overall prevalence of recorded injuries increased by $2.3 \%$ every year, HMIs recorded a $4 \%$ increase per year (Ekstrand et al., 2016).

The Nordic hamstring exercise (NHE) has been shown to be effective in increasing eccentric strength. For example, 4-10 weeks of NHE can result in an eccentric strength gain of approximately $11 \%$ to $21 \%$ with no significant concentric strength gains, and after a 6-week intervention, neural adaptations occurred, resulting in higher hamstring muscle activation during the NHE (Delahunt et al., 2016). In another study, a single NHE training session was followed by an immediate shift $\left(7.7^{\circ}\right)$ in optimum knee flexion torque, which was sustained for ten days post-exercise, and the peak eccentric hamstring torque was unchanged following 4- and 6-week NHE interventions (Seymore et al., 2017). Moreover, a 12-week NHE program decreased the rate of hamstring injury by $65 \%$ to $70 \%$ (Lovell et al., 2018).

Changes in the architectural characteristics of the biceps femoris long head (BFlh) after eccentric strength training with NHE, followed by a detraining period, were studied after eight weeks of NHE training. The findings showed an increase in the fascicle length (FL) of BFlh by $32.9 \%$, increased muscle thickness (MT), and a decrease in the pennation angle (PA), whereas the 4-week subsequent detraining showed a decrease in FL and MT as well as an increase in PA. Therefore, the authors concluded that the NHE causes alterations in the architecture of the BFlh, and this change facilitates injury prevention and rehabilitation.

The NHE can be easily performed by any athlete (Alonso-Fernandez et al., 2018) with different protocol periods; pre-training protocols for 4 weeks (Brughelli et al., 2010), 6 weeks (Seymore et al., 2017), 8 weeks (Aktuğ et al., 2018), 10 weeks (Rey et al., 2017), or up to 12 weeks (Lovell et al., 2018) all have similar effects, which is an increase in the FL of BFlh that could be due to an increase in the length of sarcomeres after eccentric strength training (AlonsoFernandez et al., 2018). Even the 4-week NHE protocol was found to be effective in decreasing the risk factors for hamstring muscle injury in young adults, and shortterm NHE training (4 weeks, twice a week, three sessions, 9-10 repetitions) with post-training assessments of knee flexor and extensor strength and flexibility showed that the training program reduced many HMI risk factors in young adults (Ribeiro-Alvares et al., 2018).
Al Attar et al. (2017) conducted a meta-analysis to evaluate the effect of injury prevention programs that include NHE on hamstring injury rates in soccer players and concluded that these injury prevention programs are effective in decreasing the risk of HMIs among soccer players, and per $1000 \mathrm{~h}$ of exposure, the teams adopting injury prevention programs with NHE showed a $51 \%$ reduction in HMIs than teams that did not adopt any injury prevention measures. In a study of 40 amateur soccer teams that compared the injury rates in teams performing NHE and in others that did not, the authors concluded that adopting the NHE for 13 weeks with regular training significantly reduced injury rates (Van der Horst et al., 2015).

Dunlop et al. (2020) published a worldwide survey of 131 soccer teams that reviewed the return-to-play (RTP) criteria they were using to support their decision-making for RTP, specifically if the athlete was ready to continue running at high speed. The results showed that the majority of teams assessed the absence of pain and hamstring strength; the authors also mentioned that hamstring strength and training load were reported more frequently than any other criteria when they returned to full training.

Nevertheless, to our knowledge, there are no published data in the literature regarding the awareness, opinions, and implementation strategies in relation to NHE among athletes in deferent sports. Therefore, the purpose of this survey was to assess the awareness, implementation, and opinion of NHE in relation to the prevention of HMIs among athletes in different sports worldwide.

\section{Materials and methods}

\section{Survey development}

There are no validated questionnaires addressing athletes' awareness, implementation, and opinion of NHE; therefore, a survey to collect information on NHE awareness and implementation among athletes and to evaluate their opinions of NHE in preventing hamstring injury was developed. The questionnaire was inspired by a review of the recent literature on HMI prevention (Ribeiro-Alvares et al., 2018; Al Attar et al., 2017; Van der Horst et al., 2015; Al Attar et al., 2019; Bahr et al., 2015; Potier et al., 2009). It consisted of three sections: awareness, implementation, and opinion. Each section contained one closed question, except for the awareness section, which had three closed questions. The questions were formulated to obtain information about the efficiency and effectiveness of the NHE program for athletes. Thus, the questionnaire consisted of six questions covering the athletes' demographics (sex, country), type of sports, awareness of NHE (Yes or No), implementation of NHE (Yes or No), and the athlete's personal opinion about the effectiveness of the exercise in preventing hamstring injury, which was rated on a scale of 0 (ineffective) to 10 (very effective).

The study protocols were approved by the Biomedical Ethics Committee, Umm Al Qura University (approval no. HAPO02K012202011496). Informed consent was obtained from all individuals included in this study.

\section{Participants and sample size}

An estimated 2 billion people globally play sports, as either amateurs or professionals. Therefore, to achieve a $3 \%$ 
confidence interval (margin of error) at a 95\% confidence level, 1500 male and female amateur and professional athletes from different countries worldwide were invited to complete the online survey on NHE.

\section{Administration and survey software}

The survey was conducted using a web-based Google Form (Alphabet Inc, Mountain View, CA) The survey was framed in English, certified translated into 10 languages (Arabic, Chinese, French, German, Italian, Japanese, Portuguese, Russian, Spanish, and Turkish), and distributed across different sports organizations worldwide. Data were collected between June 2019 and June 2021. The structured survey link explained the purpose of the study and sought consent for participation in addition to providing an avenue for communication in case the respondents had any queries. All respondents were limited to one response, and the responses were voluntary and anonymous.

\section{Statistical analysis}

Responses were organized in Microsoft Excel 2010 (Microsoft Corporation, Redmond, WA, USA) and analyzed using the Statistical Package for the Social Sciences (SPSS) version 24.0 (SPSS Inc., Chicago, Illinois, USA). Pearson's chi-squared test was used for comparison of the percentage values of the descriptive statistics. A p-value of $<0.05$ is considered significant.

\section{Results}

A total of 1142 male and female amateur and professional athletes from 152 countries completed the questionnaire (response rate, $76 \%$ ), yielding a confidence interval (margin of error) of $2.9 \%$ at a $95 \%$ confidence level.

Participant distribution according to the type of sport

The largest number of participants were from four sports, namely CrossFit, bodybuilding, football, and gymnastics, followed by other sports (Figure 1).

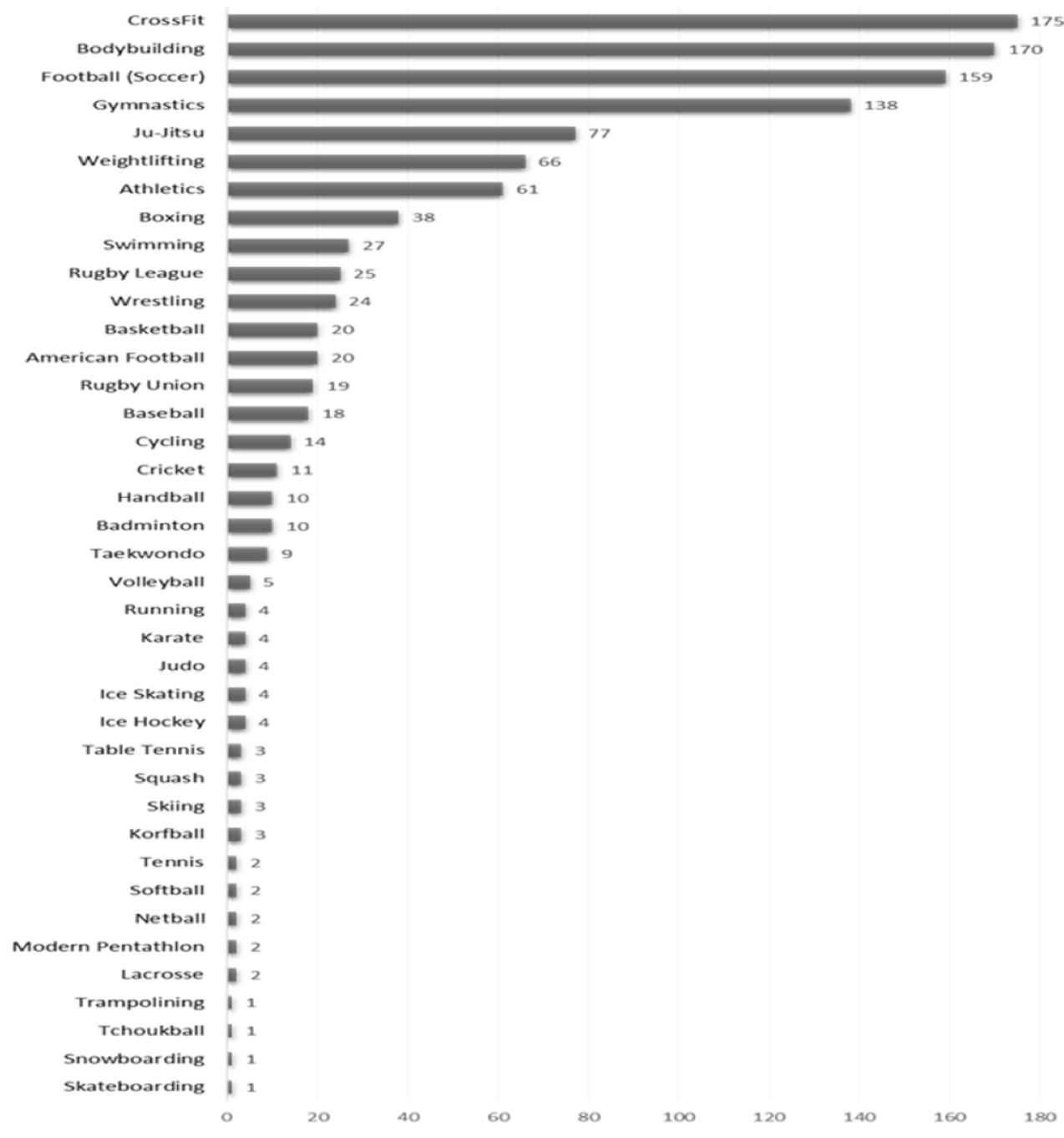

Fig. 1. Number of survey participants from different sports 


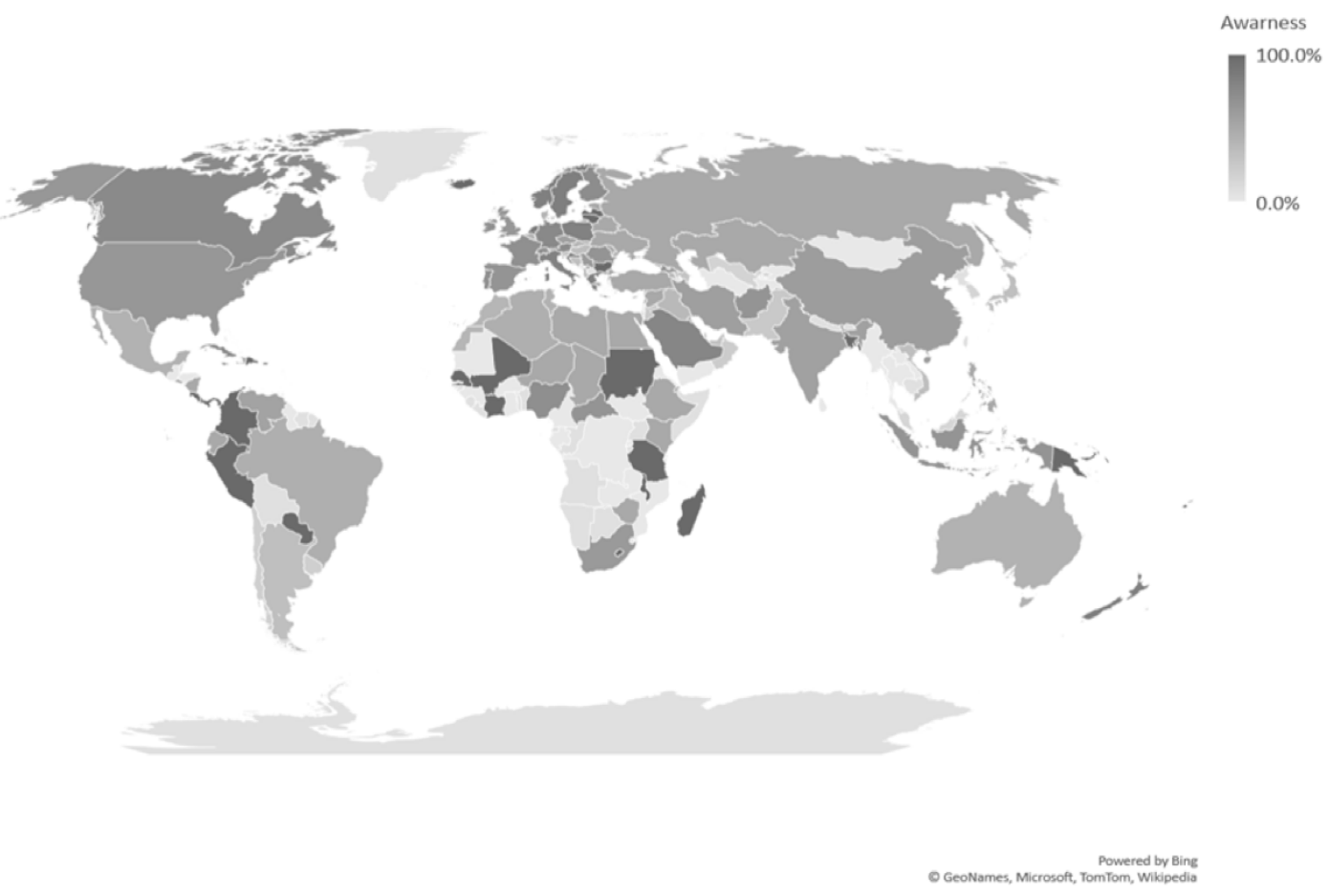

Fig. 2. Awareness of NHE worldwide

Table 1. Distribution of participants according to their continent and gender

\begin{tabular}{lrr}
\hline & No & $\%$ \\
\hline Continent & & \\
Europe & 453 & $39.7 \%$ \\
Asia & 341 & $29.9 \%$ \\
Africa & 125 & $10.9 \%$ \\
South America & 96 & $8.4 \%$ \\
North America & 75 & $6.6 \%$ \\
Australia & 52 & $4.6 \%$ \\
\hline Gender & & \\
Male & 1041 & $91.2 \%$ \\
Female & 101 & $8.8 \%$ \\
\hline
\end{tabular}

Table 2. Distribution of awareness and practice according to the participant's continent

\begin{tabular}{|c|c|c|c|c|c|}
\hline \multirow{2}{*}{ Continent } & \multicolumn{2}{|c|}{ Awareness } & \multicolumn{2}{|c|}{$\begin{array}{c}\text { Imple- } \\
\text { ment }\end{array}$} & \multirow{2}{*}{$\begin{array}{c}\text { Opinion } \\
\text { Range (Mean } \pm \\
\text { SD) }\end{array}$} \\
\hline & No & $\%$ & No & $\%$ & \\
\hline North America & 51 & 68.0 & 31 & 60.8 & $6-9(7.9 \pm 0.9)$ \\
\hline Europe & 296 & 65.3 & 258 & 87.2 & $5-10(8.6 \pm 0.9)$ \\
\hline Africa & 60 & 48.0 & 48 & 80.0 & $6-10(8.4 \pm 1.0)$ \\
\hline Asia & 172 & 50.4 & 127 & 73.8 & $5-10(8.3 \pm 1.1)$ \\
\hline Australia & 23 & 44.2 & 19 & 82.6 & $6-10(8.7 \pm 1.1)$ \\
\hline South America & 44 & 45.8 & 37 & 84.1 & $5-10(8.2 \pm 0.9)$ \\
\hline Total & 646 & 56.6 & 520 & 80.5 & $5-10(8.4 \pm 1.0)$ \\
\hline P-value & & $.001^{\times}$ & & $.001^{\star}$ & $.001^{\star \#}$ \\
\hline
\end{tabular}

P: Pearson X2 test; \#: One Way ANOVA; ${ }^{*} \mathrm{P}<0.05$ (significant)
Awareness of NHE

Among the participants who responded, $56.6 \%$ were aware of NHE, while $43.4 \%$ were unaware. The highest number of participants $(n=453)$ were from Europe, where the awareness percentage was $65.3 \%$, while North America recorded the highest awareness percentage of $68 \%$ in 75 participants. The awareness percentages of the participants from the other continents were as follows: Africa, $48.0 \%$ of 125 participants; Asia, $50.4 \%$ of 341 participants; Australia, $44.2 \%$ of 52 participants (Tables 1 and 2). A chart map was used to indicate the awareness percentages by country, and the map indicated minimal or no awareness of NHE among participants in some countries (Figure 2).

Implementation of NHE

Among the participants who were aware of the NHE, 520 athletes were implementing the NHE in their training (Table 2).

Opinions of $\mathrm{NHE}$

Among the participants who implemented the NHE, the total opinion for many participants from different continents regarding the effectiveness of NHE was a mean of $8.4 \pm 1.0$ out of 10 . The opinion section of the survey included a scale of efficacy from 0 (ineffective) to 10 (highly effective), and most implementers of NHE found it to be effective in reducing hamstring injury (Tables 1 and 2).

\section{Discussion}

In the literature, HMIs represent the most frequently reported injuries, and the incidence of these injuries has increased in the last decade with high rates of recurrences and poor outcomes for athletes despite the adoption of preventive measures and strategies and the extensive knowledge of the mechanisms underlying these injuries (Van der Horst et 
al., 2018). Therefore, this study aimed to address athletes' knowledge of well-established preventive protocols, such as the NHE, which has proven to be effective for decreasing injury rates by at least 50\% (Al Attar et al., 2017). A crosssectional survey study was conducted to assess three new criteria: athletes' awareness of the NHE program, their implementation of this program in their exercise routines, and their opinions about the effectiveness of this program in decreasing hamstring injury rates. Within the limitations of the study, our results showed that most of the respondents were from Europe and Asia (39.7\% and 29.9\%, respectively), and the overall awareness of the NHE was $56.6 \%$ worldwide. Moreover, football (soccer) athletes represented the thirdlargest population of respondents (13.9\%), after CrossFit (15\%) and body building (14.9\%).

The highest awareness percentages were recorded in North America and Europe (68\% and $65.3 \%$ of the respondents, respectively). This finding was not surprising because these regions have highly developed sports medicine systems that employ a number of measures to ensure athlete safety, increasing their adoption of injuryprevention protocols. Europe is considered the home of injury prevention programs since Jan Ekstrand published the first-ever injury prevention program in the literature for professional football in 1982 (Ekstrand et al., 1982).

Surprisingly, the results of the current study showed that Australia occupied the last place in participation, representing only $4.6 \%$ of the overall sample size, and it showed the lowest awareness percentage (44.2\%). The Australian literature is extraordinarily rich in publications about the importance of injury prevention protocols and their effectiveness in decreasing injury rates (Al Attar et al., 2016) and even includes an evidence-based study for the implementation of injury prevention studies in football (Al Attar et al., 2018), confirming the presence of a gap between research and actual practice. However, the low awareness rate may also be attributable to the low response rate from Australia in comparison to those from the other continents.

Despite the conventional logic that greater awareness leads to greater implementation, the study results showed some notable differences between the trends in awareness and implementation. For example, despite showing the highest awareness percentage, athletes from North America showed a low implementation percentage of $60.8 \%$, which was the lowest among the continents assessed in this study. In contrast, Europe, which showed the second-highest awareness rate, showed the highest implementation rate $(87.2 \%)$. The implementation rates in other regions of the world were similar and ranged between $73.1 \%$ and $84.1 \%$.

In the assessments of effectiveness, all rating results were similar with the highest mean value (8.7) obtained for athletes from Australia. The lowest mean value (7.9) was reported for athletes from North America. Despite showing the highest level of awareness of NHE, North American athletes showed the lowest level of NHE implementation, which may be one reason for the low opinion of effectiveness of NHE in athletes from this region. However, these low levels of perceived effectiveness of NHE in North American athletes have not been reported in the literature until now.

Bahr et al. conducted a survey study to determine the efficacy, adoption, and implementation of the NHE program among elite male soccer players in Europe from 2012 to
2014 , and although they obtained a response rate of $100 \%$ across 150 club seasons, only $10 \%$ of the respondents adopted a protocol; the extremely low adoption rate resulted in a compliance rate that was too low to show any effect on hamstring injury rates (Bahr et al., 2015). The evidence from this study could explain the low effectiveness score rated by North American athletes, which may be most probably attributed to their low implementation percentages for the preventive protocol. Thus, consistent with previous literature, that a gap still exists between the awareness of the injury's occurrence and implementation of preventive measures. Furthermore, Al Attar et al. (2021) found limited implementation of the NHE in professional and semiprofessional soccer. An online survey was completed by 812 (88.3\% male and $11.7 \%$ female) players and coaches. Of these, 395 (48.6\%) were aware of the NHE, and 355 (43.7\%) implement it in their current practice. Those implementing NHE had a positive opinion about its efficacy in reducing hamstring injuries.

This study had multiple limitations. It was not possible to control the percentage of respondents worldwide and the number of athletes responding from each country to obtain the most representative results. Athletes in some countries did not respond to the online survey, which affected the overall percentages of those regions in comparison with other regions of the world. Nevertheless, many of the results reported herein do not have supporting data or explanations in the existing literature; for example, North American athletes showed the highest awareness of the NHE but also showed an extremely low implementation rate. This study thus presents the scope for new research on the topic of NHE implementation in low-implementation regions, such as Asia and North America. In addition to highlighting gaps between awareness and actual implementation, this study also revealed gaps in awareness in some regions, such as Australia and South America. More research is needed on the topics connecting the three factors, and region-specific studies, instead of the global limited study conducted herein, may be more useful to understand these trends. Thus, the present study presents the scope for additional research on these topics for different regions and indicates the need for region-specific studies to understand the gaps in implementation and awareness (or the effectiveness) of the program.

Appropriate implementation of injury prevention programs is an important factor that affects the health of athletes; therefore, more research is needed to increase awareness in regions, such as Asia, where both implementation and awareness percentages were found to be relatively low. Additional studies are also required to evaluate the opinions regarding the effectiveness of the NHE because this study showed that the actual effectiveness of the NHE is low in some regions.

\section{Conclusions}

Most athletes around the world are aware of NHE and are implementing it in their exercise training routine because they find it effective in decreasing hamstring injury rates. However, additional work must be done to educate athletes about the importance of implementing this exercise because the adoption percentages differ significantly worldwide. 
Athletes who adopt the NHE usually find it to be highly effective in reducing hamstring injury rates.

\section{Acknowledgement}

The author acknowledges Drs Eman Aljedaani, Amirah Akkam, Nada Alhazmi, Hussain Ghulam, Hend A. Dorgham and Professor Ross Sanders for their expertise and assistance throughout all aspects of this study and for their help in writing the manuscript. I express my gratitude to all athletes who spent their valuable time participating in this research. The author would like to thank Falcon Scientific Editing (https://falconediting.com) for proofreading the English language in this paper.

\section{Conflict of interest}

The authors declared no conflicts of interest.

\section{References}

Reurink, G., Tol, J. L., \& de Vos, R-J. (2014). Acute hamstring injuries in athletes [in Dutch]. Ned Tijdschr Geneeskd, 159, A8152

Ueblacker, P., Müller-Wohlfahrt, H. W., \& Ekstrand, J. (2015). Epidemiological and clinical outcome comparison of indirect ("strain") versus direct ("contusion") anterior and posterior thigh muscle injuries in male elite football players: UEFA Elite League study of 2287 thigh injuries (2001-2013). Br J Sports Med., 49(22), 1461-1465. https://doi.org/10.1136/bjsports-2014-094285

Ekstrand, J., Healy, J. C., Waldén, M., Lee, J. C., English, B., \& Hägglund, M. (2012). Hamstring muscle injuries in professional football: the correlation of MRI findings with return to play. Br J Sports Med., 46(2), 112-117. https://doi.org/10.1136/bjsports-2011-090155

De Vos, R. J., Reurink, G., Goudswaard, G. J., Moen, M. H., Weir, A., \& Tol, J. L. (2014). Clinical findings just after return to play predict hamstring re-injury, but baseline MRI findings do not. Br J Sports Med., 48(18), 1377-1384. https://doi.org/10.1136/bjsports-2014-093737

Chumanov, E. S., Heiderscheit, B. C., \& Thelen, D. G. (2011). Hamstring musculotendon dynamics during stance and swing phases of high-speed running. Med Sci Sports Exerc., 43(3), 525-532. https://doi.org/10.1249/MSS.0b013e3181f23fe8

Ropiak, C. R., \& Bosco, J. A. (2012). Hamstring injuries. Bull NYU Hosp Jt Dis, 70(1), 41-48.

Hägglund, M., Waldén, M., Bengtsson, H., \& Ekstrand, J. (2018) Re-injuries in Professional Football: The UEFA Elite Club Injury Study. In: Musahl V., Karlsson J., Krutsch W., Mandelbaum B., Espregueira-Mendes J., d'Hooghe P. (eds) Return to Play in Football. Springer, Berlin, Heidelberg. https://doi.org/10.1007/978-3-662-55713-6_74

Dadebo, B., White, J., \& George, K. P. (2004). A survey of flexibility training protocols and hamstring strains in professional football clubs in England. Br J Sports Med., 38(4), 388-394. https://doi.org/10.1136/bjsm.2002.000044

Yeung, S. S., Suen, A. M. Y., \& Yeung, E. W. (2009). A prospective cohort study of hamstring injuries in competitive sprinters: preseason muscle imbalance as a possible risk factor. Br J Sports Med., 43(8), 589-594. https://doi.org/10.1136/bjsm.2008.056283

Ekstrand, J., Waldén, M., \& Hägglund, M. (2016). Hamstring injuries have increased by $4 \%$ annually in men's professional football, since 2001: a 13-year longitudinal analysis of the UEFA Elite Club injury study. Br J Sports Med., 50(12), 731-737.

https://doi.org/10.1136/bjsports-2015-095359

Delahunt, E., McGroarty, M., De Vito G., \& Ditroilo M. (2016). Nordic hamstring exercise training alters knee joint kinematics and hamstring activation patterns in young men. Eur J Appl Physiol., 116(4), 663-672. https://doi.org/10.1007/s00421-015-3325-3

Seymore, K. D., Domire, Z. J., DeVita, P., Rider, P. M., \& Kulas, A. S. (2017). The effect of Nordic hamstring strength training on muscle architecture, stiffness, and strength. Eur J Appl Physiol., 117(5), 943-953. https://doi.org/10.1007/s00421-017-3583-3

Alonso-Fernandez, D., Docampo-Blanco, P., \& MartinezFernandez, J. (2018) Changes in muscle architecture of biceps femoris induced by eccentric strength training with Nordic hamstring exercise. Scand J Med Sci Sports., 28(1), 88-94. https://doi.org/10.1111/sms.12877

Lovell, R., Knox, M., Weston, M., Siegler, J. C., Brennan, S., \& Marshall, P. W. M. (2018). Hamstring injury prevention in soccer: before or after training? Scand J Med Sci Sports. 28(2), 658-666. https://doi.org/10.1111/sms.12925

Brughelli, M., Mendiguchia, J., Nosaka, K., Idoate, F., Arcos, A. L., \& Cronin J. (2010). Effects of eccentric exercise on optimum length of the knee flexors and extensors during the preseason in professional soccer players. Phys Ther Sport., 11(2), 50-55. https://doi.org/10.1016/j.ptsp.2009.12.002

Aktuğ, Z. B., Yılmaz, A. K., İbiş, S., Aka, H., Akarçeşme, C., \& Sökmen, T. (2018). The effect of 8-week Nordic hamstring exercise on hamstring quadriceps ratio and hamstring muscle strength. World J Educ., 8(3), 162-169. https://doi.org/10.5430/wje.v8n3p162

Rey, E., Paz-Domínguez, Á., Porcel-Almendral, D., ParedesHernández, V., Barcala-Furelos, R., \& Abelairas-Gómez, C. (2017). Effects of a 10-week Nordic hamstring exercise and Russian belt training on posterior lower-limb muscle strength in elite junior soccer players. J Strength Cond Res., 31(5), 1198-1205. https://doi.org/10.1519/JSC.0000000000001579

Ribeiro-Alvares, J. B., Marques, V. B., Vaz, M. A, \& Baroni, B. M. (2018). Four weeks of Nordic hamstring exercise reduce muscle injury risk factors in young adults. $J$ Strength Cond Res., 32(5), 1254-1262. https://doi.org/10.1519/JSC.0000000000001975

Al Attar, W. S. A., Soomro, N., Sinclair, P. J., Pappas, E., \& Sanders, R. H. (2017). Effect of injury prevention programs that include the Nordic hamstring exercise on hamstring injury rates in soccer players: a systematic review and meta-analysis. Sports Med., 47(5), 907-916. https://doi.org/10.1007/s40279-016-0638-2

Van der Horst, N., Smits, D. W., Petersen, J., Goedhart, E. A., \& Backx, F. J. (2015). The preventive effect of the Nordic 
hamstring exercise on hamstring injuries in amateur soccer players: a randomized controlled trial. Am J Sports Med., 43(6), 1316-1323.

https://doi.org/10.1177/0363546515574057

Dunlop, G., Ardern, C. L., Andersen, T. E., Lewin, C., Dupont, G., \& Ashworth, B. et al. (2020). Return-to-play practices following hamstring injury: a worldwide survey of 131 premier league football teams. Sports Med., 50(4), 829840. https://doi.org/10.1007/s40279-019-01199-2

Al Attar, W. S. A., \& Alshehri, M. A. (2019). A meta-analysis of meta-analyses of the effectiveness of FIFA injury prevention programs in soccer. Scand J Med Sci Sports., 29(12), 1846-1855. https://doi.org/10.1111/sms.13535

Bahr, R., Thorborg, K., \& Ekstrand, J. (2015). Evidence-based hamstring injury prevention is not adopted by the majority of Champions League or Norwegian Premier League football teams: the Nordic Hamstring survey. $\mathrm{Br} J$ Sports Med., 49(22), 1466-1471.

https://doi.org/10.1136/bjsports-2015-094826

Potier, T. G., Alexander, C. M., \& Seynnes, O. R. (2009). Effects of eccentric strength training on biceps femoris muscle architecture and knee joint range of movement. Eur J Appl Physiol., 105(6), 939-944.

https://doi.org/10.1007/s00421-008-0980-7
Van der Horst, N. (2018). Preventing hamstring injuries in football through enhanced exercise and RTP strategies. Br J Sports Med., 52(10), 684-685. https://doi.org/10.1136/bjsports-2017-098630

Ekstrand, J., Gillquist, J. (1982). The frequency of muscle tightness and injuries in soccer players. Am J Sports Med., 10(2), 75-78. https://doi.org/10.1177/036354658201000202

Al Attar, W. S. A, Soomro, N., Pappas, E., Sinclair, P. J., \& Sanders, R. H. (2016). How effective are F-MARC injury prevention programs for soccer players? A systematic review and meta-analysis. Sports Med., 46(2), 205-217. https://doi.org/10.1007/s40279-015-0404-X

Al Attar, W. S. A., Soomro, N., Sinclair, P. J., Pappas, E., Muaidi, Q. I., \& Sanders, R. H. (2018). Implementation of an evidence-based injury prevention program in professional and semi-professional soccer. Int J Sports Sci Coaching, 13(1), 113-121. https://doi.org/10.1177/1747954117707482

Al Attar, W. S. A., Komir, R., Alzubeadi, A., Bukhari, I., \& Ghulam, H. (2021). Limited implementation of the Nordic hamstring exercise in professional and semiprofessional soccer. Journal of Orthopaedics, Trauma and Rehabilitation, 28, 1-7. https://doi.org/10.1177/22104917211008637

\title{
ПОТОЧНА РЕАЛІЗАЦІЯ НАУКОВО ОБҐРУНТОВАНОЇ ВПРАВИ ПО ЗАПОБІГАННЮ ТРАВМ ПІДКОЛІННОГО СУХОЖИЛЛЯ (СКАНДИНАВСЬКА ВПРАВА НА ПІДКОЛІННЕ СУХОЖИЛЛЯ) СЕРЕД СПОРТСМЕНІВ У ВСЬОМУ СВІТІ
}

\author{
Весам Салех А. Аль Аттар ${ }^{1,2,3 \mathrm{ABCDE}}$ \\ ${ }^{1}$ Університет Умм Аль Кура \\ ${ }^{2}$ Університет Сіднея \\ ${ }^{3}$ Базельський університет \\ Авторський вклад: А - дизайн дослідження; В - збір даних; C - статаналіз; D - підготовка рукопису; Е - збір коштів \\ Реферат. Стаття: 7 с., 2 рис., 2 табл., 29 джерел.
}

Мета. Скандинавська вправа на підколінні сухожилля (NHE) виявилася успішною у зменшенні травми м'язів підколінного сухожилля (НMI), яка є однією з найпоширеніших безконтактних травм нижніх кінцівок. Це особливо доречно у видах спорту, які вимагають прискорення, максимальних спринтів та різких змін напрямку бігу та спринту, таких як футбол та регбі. Це дослідження мало на меті оцінити обізнаність, реалізацію та думки спортсменів у всьому світі щодо ефективності NHE у запобіганні травм підколінного сухожилля.

Матеріали та методи. Анкету для самостійного розповсюдження було роздано 1500 спортсменам з різних видів спорту. Опитування складалося з шести питань, що охоплюють країну, стать, вид спорту, обізнаність, використання та думки спортсменів у всьому світі щодо ефективності NHE у запобіганні травмам підколінного сухожилля. Опитування було доступне десятьма різними мовами.
Результати. Всього в опитуванні взяли участь 1142 спортсмени з різних видів спорту. Більше половини спортсменів 641 (56\%) знали про NHE, і лише 519 (45,4\%) впроваджували NHE у своїх поточних тренувальних процедурах. Спортсмени, які впровадили NHE, вказують на ефективність програми з оцінкою 8,4 11310 .

Висновки. Більшість спортсменів знали про NHE та впроваджували їі у свої тренувальні процедури, оскільки вважали, що вона ефективна у зниженні частоти травм сухожиль. Однак необхідно докласти додаткових зусиль, щоб сформувати знання спортсменів про важливість виконання цієї вправи та її ефективність у запобіганні травм сухожилля.

Ключові слова: м'язи підколінного сухожилля, травми м'язів, спортсмени, опитування, анкетування. 


\section{Information about the authors:}

Wesam Saleh A. Al Attar, PT, MSc, PhD: wsattar@uqu.edu.sa; https://orcid.org/0000-0003-1907-4539; Department of Physical Therapy, Faculty of Applied Medical Sciences, Umm Al Qura University, PO Box: 715, Makkah, 21955, Saudi Arabia. Discipline of Exercise and Sport Science, Faculty of Medicine and Health Sciences, The University of Sydney, Australia; Department of Sport, Exercise and Health, Faculty of Medicine, University of Basel, Basel, Switzerland.

Cite this article as: Wesam Saleh A. Al Attar (2021). The Current Implementation of an Evidence-Based Hamstring Injury Prevention Exercise (Nordic Hamstring Exercise) among Athletes Globally. Teoriâ ta Metodika Fizičnogo Vihovannâ, 21(3), 273280. https://doi.org/10.17309/tmfv.2021.3.11

Received: 03.09.2021. Accepted: 17.09.2021. Published: 25.09.2021

This work is licensed under a Creative Commons Attribution 4.0 International License (http://creativecommons.org/licenses/by/4.0). 